\title{
Environmentalism as a Stakeholder Issue and a Research for the Environmental Awareness of University Students
}

\author{
Kurtuluş Yılmaz Genç ${ }^{1} \&$ Betül Çal ${ }^{1}$ \\ ${ }^{1}$ Giresun University, Faculty of Economics and Administrative Sciences, Giresun, Turkey \\ Correspondence: Kurtuluş Yılmaz Genç, Giresun University, Faculty of Economics and Administrative Sciences, \\ Giresun, Turkey. Tel: 90-534-212-2951. E-mail: kyilmazgenc@gmail.com
}

Received: March 18, 2015

Accepted: May 15, 2015

Online Published: May 22, 2015

doi:10.5539/ijbm.v10n6p113

URL: http://dx.doi.org/10.5539/ijbm.v10n6p113

\begin{abstract}
The basic aim of this paper is to investigate the awareness to environmental issue by conducting a research on 484 university students of Giresun University, Turkey. A total of 484 participants were reached, however only 466 were found to be valid for the data analysis process. The participants were mainly the 2nd and 4th year-undergraduates studying at the departments of Economics, Business Management and International Relations, and took part in the questionnaire on a voluntary basis. Data obtained from those 466 questionnaires analyzed through the SPSS statistical package program, and 21 possible relations were tested. The analysis of the data indicates that, the populations of cities residence before their university education, their attitudes to environmental issues, and the information about purchased goods have hazardous effects against the environment, purchasing behavior to a firm which gives harm to environment, and the participants thought on environmental issues are statistically significantly associated. And also, the participants experiences about environmental issues and their gender is positively linked.
\end{abstract}

Keywords: environmental awareness, environmental issue, university students, Turkish practice, Giresun University

\section{Introduction}

The environmental issue is one of the main problems of humanity, as a contrast, related to its attitudes, behaviors, or actions. Accordingly, there is an intense effort, to provide the support of people to the actions or struggle against the environmental destruction, beginning especially from 1970's. So, thesis, articles, or books were written to discuss the issue and suggest solutions, or behavioral types, to protect natural balance, and provide sustainability for all areas of life. Hence, it is this awareness that would make our earth safer for future generations.

In Turkey, the environmental issue was largely taken in to account in the decisions of the state and corporations beginning from early 1980's. Although the industrialization process began in 1930's, the striking development started with the polluted air of enlarging cities, especially Ankara, Istanbul, and Izmir. These are the industrial hubs of Turkey. In those decades, coal was being used as a resource for heating in these large cities. Therefore, many health problems were lived as a result of this situation including the symptoms of asthma, related infections and diseases. Hence, the consequences of the polluted environment, especially the polluted air made constructed awareness among people about this issue. Then, the state and business organizations have to respond this sensitivity.

It is obvious that, to keep or make companies 'green' an effective stakeholder influence or 'green pressure' is needed. This pressure is largely and routinely being felt in developed countries. Thus, the firms in these countries give high level importance to this issue, and making many things to create an 'environmentally friendly' image on public, and to be an environmentalist. Also, in developing countries, the environmental issue becoming one of the important titles of agenda. In these countries stakeholders should force companies more, and try to make them respond 'public interest'.

Students as a stakeholder group of for-profit or not-for profit organizations, are usually one of the important social elements that reflect public opinion bravely, depending on their age, or nature. This study was designed to reveal the assumed sensitivity, and concern among students for environmental issue. In Turkey, like in European 
or Far Eastern Asian countries, 'student sensitivity' is one of the basic dimensions of social and political life. Today, this sensitivity can be observed against gold mining operations, thermoelectric power plant construction or related municipality activities, in Turkey. Therefore, it would be interesting to learn and reveal what they think about some environmental issues in general.

The attitudes of people can change due to their gender, income, the population of city they live or come from, or their education level. Thus, this study was based on the hypothesis reflecting these proposals. So, it investigates the level of awareness of students about the natural environmental issue, depending on a research conducted on university students. Accordingly, in the first part of the paper, related literature is discussed. Then, in the second part, the results of the field research are given and evaluated; and finally, a general conclusion is presented.

\section{Literature Review}

\subsection{Sustainable Development: A Vital Concept for Humanity}

As today's one of the main issues, sustainability reflects the future of the earth, so the humanity. This planet can continue to be the home for next generations if it can protect or maintain its main characteristics. Thus, this concept depends on a balance between human and the nature. So, when this balance breaks up the future of humanity will be in a very risky position. Hence, the development activities should be based on the consideration and sensitivity to this issue, in terms of benefiting from natural resources in a rational way, and make them variable for the usage of next generations.

The term sustainability includes being 'environmentally friendly', and it was first used by World Council of Churches in 1974. The term was suggested by western environmentalists to respond the worries of societies who are living in the conditions of poverty undeveloped or developing countries. In 1980, 'sustainable development' term became more known by the contribution of International Union for Conservation of Nature and Natural Resources. The current form of sustainability was created by United Nations' World Commission on Environment and Development, with the report of 'Our Common Future', in which the term was changed as 'sustainable development'. It was declared in that report that, 'sustainable development was about both equity between generations and equity within generations'. So, 'development should meet the needs of the present with compromising the ability of future generations to meet their needs' (Dresner, 2002). It is clear that, the principles of economic development and environmental quality will strengthen each other (Kleiner, 1991); so, a common approach which focuses on balance is needed to be developed and implemented.

It is obvious that sustainability has dimensions of both 'economic growth' and 'environmental protection'. But in general, it includes environmentally friendly action in the process of economic development to make life continuous on earth. So, the usage of renewable energy and material should be maximized, and the waste that is given to environment should be minimized. So, pollution prevention or the rational usages of materials are also important behaviors to contribute a sustainable earth.

On the whole, economic activities should be efficient, and socially, environmentally, and ecologically sustainable. Equally, it should be aimed to respond physical, mental, emotional and spiritual needs of human with minimum usage of limited resources. Again, the distribution of skills and materials should be distributed efficiently. Also, the technology that is used, should contribute to ecological balance (Davis, 1991). Thorough these, the interests of future generations and other societies will be protected. Hence, a sustainable life and economy can be realized.

As it can be seen in the explanations above the sustainable development of economies or countries requires a comprehensive approach, integrating and considering all the dimensions in the process of economic advance. On the other hand, the stakeholders are important elements to encourage or force states and firms to behave through the common interests of society.

\subsection{Corporate Environmentalism and the Business Organization in Today's Complexity}

Today, corporate environmentalism includes integrating public concern into the strategy design and implementation process. As examined by many writers (e.g. Banerjee, 2001a; Banerjee, 2001b; Banerjee, 2002b; Kleiner, 1991; Taylor, 1992) examined in details the concept or 'action' includes democratic participation, support and integrity in the organization, as a strategic tool looking to long term, behaving socially responsible, commitment to quality, considering customers and society's demand and expectations, putting into account the environmental impact in every step of manufacturing process, and product development. Moreover, it includes a clear focus on waste production, recycling, packaging, and pollution control. Finally, it requires a full compromise with all stakeholders to act together to protect natural balance.

One of the most important aspects of corporate environmentalism is 'what is good for a company, it is also good 
for natural environment'. This might be the main slogan that firms' should take into account in related processes.

\subsection{Related Studies}

Taylor (1992) discussed the corporate environmentalism as a strategic tool to achieve competitive advantage, through cost savings, new marketing opportunities, good corporate image, creating new opportunities, and increasing employee motivation. Walley and Whitehead (1994) examined the win-win approach, stressing the gains from environmental policies and practices. Hart and Ahuja (1994) argued that environmental performance is an important indication of organizational performance. Similarly, Hart (1995) argued that, to consider public concern in product development process, and preventing pollution might contribute firms to achieve competitive advantage. Equally, Porter and Linde (1995) discussed the importance of innovations to reduce costs, and stated that to use inputs more productively might lead firms to competitive advantage. Furthermore, Fineman (1997) explained the importance of green stakeholders and their sophistication in their methods. Again, Fineman and Clarke (1996) examined the 'industrial responses to green pressure'. Also, Bianchi and Noci (1998) identified direct and indirect roles for stakeholders on the environmental performances of firms. Accordingly, they achieved that, research centers, industrial unions and manufacturer associations are the key factors for the firms' network of environmental services, and they support these organizations to have better environmental performances to respond external requirements. In the same way, Judge Jr., and Douglas (1998) achieved the result that companies that integrate environmental issue in a better way, responding stakeholder concern, would have much more revenues and better social outcomes. Again, Rugman and Verbeke (2000) developed a resource-based perspective on 'green' strategies in an international context; and identified competitors, buyers, suppliers' impact on related issues. Similarly, Stead and Stead (2000), discussed corporate environmentalism in the frame of enterprise strategy, which they called eco-enterprise strategy. Their study also includes an ethical focus; and they developed a green stakeholder map. Besides, Rojsek (2001) found that, interest groups as a source of pressure for better performance are respectively top management, government, competitors and consumers, and environmentalists. Conversely, employees and shareholders have very law level of influence; and distributers and suppliers have no impact on environmental decisions. Banerjee (2001a, 2002a) found that environmental concern was a two-dimensional construct: internal concern and external concern. Internal concern is the level of inherent concern a person has for the environment, which includes its personal relevance, interest in environmental issues; worrying about environmental pollution, feeling a nature of connectedness with the nature, and caring about the environment. External concern is about benefits of consumer products oppose to pollution, effect of environmental regulation on industry, and economic trade-offs (Banerjee, 2001a; Banerjee, 2002a). Banerjee (2001a) explored that the correlation between internal environmental concern and environmental behavior was significantly higher than between external environmental concern and behavior. Banerjee (2002a) discusses the emergence of environmental issues and their implications for strategy, and also describes the theoretical and practical implications of integrating environmental and social issues into corporate strategies. Equally, due to the results of another empirical study, Banerjee (2002b) stated that, there were significant differences in how internal and external factors influenced corporate environmentalism. Regulatory, public concern and top management commitment were all found to be positive integrated with corporate environmentalism. In addition, Banerjee (2001b) found that public concern is one of the main external factors affecting environmental strategies design and implementations of a firm. In Turkey, Çabuk and Karacaoğlu (2003) achieved that, the environmental sensitivity levels of university students change according to their age, gender, and departments. On the other hand, Oğuz et al. (2011) pointed out that, the students' sensitiveness for environmental issues does not change according to their classes. In addition, Ayyıldız and Genç (2008) conducted a survey on university students and found that, respondents had significant awareness on environmental issues; and they were ready to support related actions.

\subsection{Corporate Environmental Orientation: A Necessary Practice}

Today, corporate environmentalism is one of the main topics of business world, related with the growing concerns about the sustainability of our planet earth. Therefore, as one of the most important polluters, firms should reevaluate their policies and practices to protect the balance of nature, and respond the enlarging demands or expectations of people.

As the awareness and the sensitiveness of people increases, their concern about natural environment becoming more systematic, which are reflected in their behaviors, or actions? In relation to this, Decker (2003) searched the environmental policy and the economic advantages relation, and, found that these are related. Similarly, Perkins (2007) discussed corporate environmentalism and showed that, the concept is closely linked with growing international political engagement, market integration, and transnational social communication. 
Banerjee (2001c) states that environmental issue is related with organizational strategy in terms of "environmental issues on strategic choices, internal structure reform, supply chain management, stakeholder management and competitive advantage".

Attempts to incorporate the biophysical environment into organization theory have resulted in two main areas of research. One area uses an interdisciplinary approach and discusses the paradigmatic implications as the biophysical environment into traditional economic and management paradigms. These paradigms are such as "ecocentric paradigm", and the "sustaincentric paradigm" (Gladwin et al., 1995; Starik \& Rands, 1995). Ecocentric paradigm highlights that there are limits to growth and carrying capacity and is sceptical about the role of technology in solving environmental problems (Gladwin et al., 1995; Banerjee, 2001b). Galdwin et al. (1995) discuss the "technocentric" paradigm which depends on limitless growth and reliance on science and technology to solve environmental problems. As a contradiction; "ecocentric" paradigm states that there are limits for "growth" and the carrying capacity of the planet as well. "Sustaincentric" paradigm is a synthesis of technocentric and ecocentric paradigms that moderates the excess and zero growth and presents conciliation (Banerjee, 2001b; 2002a; 2003).

Egri and Pinfield (1996) distinguish between radical environmentalism and reform environmentalism; these two are positioned as being opposed to the dominant social paradigm of limitless growth and infinite natural resources. The dominant theme of reformist view is that; organizations are accountable to all their stakeholders; this is the basis of corporate environmentalism which is a response to the stakeholders' interests. Stakeholders are all those groups who can affect, or affected by organizations. Regulatory agencies, the local community, and environmental agencies are also among stakeholder that firms should take into consideration (Banerjee, 2001b). Recognizing "green" stakeholders (regulatory agencies, environmental agencies, and environmentally conscious consumers) could significantly influence an organization's level of corporate environmentalism. Corporate environmentalism provides a moral and ethical framework for organizational decision-making which has limited implications for corporate strategy (Banerjee, 2001b).

As mentioned by Banerjee (2001b; 2002b) natural environmental orientation includes making every employee to be aware of environmental issues and participate in environmental activities and understand the importance of environmental preservation. Environmental awareness should be established in every levels of organizational structure to reach a strong action that reflects firm's priorities. Also, environmental thought and action should be a part of organizational culture as a basic value as a way of implementing societal responsibility. Firms should take all the environmental actions and so the preservation as a compulsory behavior for the survival of organizations alike individuals.

Environmental activities of a firm facilitate to form close links with its customers, also it is a way of attracting all customers who are sensitive to this issue. An environmental philosophy affecting organizational climate will facilitate unity in a firm and encourage employees to contribute firm's environmentally friendly public image. By this way firm will have the chance to sell more, to product more, to have more opportunities of improving itself, in terms of diversification of goods or services and ways of contact public and finally become larger. Today, environment is a global issue, and issue of humanity, so nobody or neither of the organizations can keep themselves out of this.

One of the most important dimensions of corporate environmental orientation is the concept of resource productivity (Porter \& Linde, 1995) which allows companies reduce full system costs and increase value for any product. The incomplete usage of materials, inadequate process controls result in extravagant waste, faulty products and unnecessarily stored materials. Moreover, packaging adds new costs and the consumption of products also a reason for pollution and energy usage.

Although, environmental activities causes some cost, by increasing efficiency it gives more than it takes, so in a way it also presents the basis of success or profitability (Banarjee, 2002b). Firms owning this issue and process seriously will also be more attractive for consumers who pay attention to that kind of company identity. An environmentally friendly behavior type will also manage to get rid of any undesirable state penalties or punishments which is also a kind of cost for firms. Any one, any individual or any organization can be benefited from environmental action.

\subsection{Environmental Strategies of Organizations: New Opportunities in Competitiveness}

In order to survive in the competition, the environmentally friendly action can be a major tool for companies (Taylor, 1992). As Porter and Linde (1995) stressed pollution equals to inefficiency for organizations, which demonstrates the significance of adding environmentalist view to organizational strategy. Also, an enterprise strategy can be stronger with the integration of ecological concerns into it. Therefore it can be called as 
'eco-enterprise strategy', which can be based on an ethical consideration to maintain a balance among human generations, other livings, or elements of biophysical environment (Stead \& Stead, 2000). This also demonstrates an 'ecological stability', which would sustain a general wellness on earth.

The integration of environmental concern into the strategy process would contribute to the common home earth, by making life sustainable. Moreover, this action might make firms more competitive with the satisfaction, and so, support of especially 'green stakeholders'. In other words, environment focused innovation would lead firms better positions in business life (Davis, 1991; Dresner, 2001; Hart, 1995, p. 1002; Jose, 1996; Kallio \& Nordberg, 2006; Lessem, 1991, p. 1; MacNeill et al., 1991; Taylor, 1993; Warford, 1989).

Environmental issues should be integrated to firms' strategic plan process. This is the most important point of environmental strategy, to put environmental action as a part of organizational strategy. Environmental issues should also be integrated into all functional areas of business, and all employees of a firm are required to be responsible for developing initiatives. Accordingly, firms that have an environmentally friendly approach should have a "quality" view which also includes reducing environmental impact of the organization. At those firms environmental objective should be linked with other corporate goals; they should develop products and processes that minimize the environmental impact. Environmental issues should be a part of planning process, and so environmental issues should be in consideration in every new product design process or technology decisions (Banerjee, 2001b; 2002b; Hart, 1995; Taylor, 1992; Walley \& Whitehead, 1994). As a public relations policy all the environmental aspects, influences of a firm's products and services need to be shown on the package or ads, so that a relationship depending on thrust could be set between firm and consumers. This is also beneficial to obey rules, to behave under legacy and to avoid of any penalties and punishments. Firms are legally responsible for their actions affect natural environment. There must be instructions in all firms for managers, employees to manage processes, situations to reach relevant goals. Also, all these instructions, so the actions, products and services should be based upon standards which also can be performance criteria. Environmentally friendly behaviors of firms fulfill firms' strategic approach and strengthen its competitiveness. Environmentally friendly goods and services give firms opportunities to enlarge markets to increase profitability, and to gain public support also facilitates sells of other goods.

\subsection{Stakeholders as Elements to Encourage Firms for Corporate Environmentalism}

Any corporation should respond to the needs and expectations of its stakeholders. Clarkson (1995) defines stakeholders as individuals or groups who influence an organizations activities and being influenced by them. The stakeholders of a firm include shareholders, employees, customers, state, society, universities, employment agencies, suppliers, distributers, competitors, non-governmental organizations, and other elements that have mutual interests with a firm. Thus, establishments can have competitive advantage depending on this type of strength.

Green consumers are those 'who want ecological and social responsibility built into the products they buy, are a complex, diverse group that vary in terms of motives, levels of ecological commitment and so forth' (Stead \& Stead, 2000). On the other hand, environmental pressure groups becoming more sophisticated (Fineman, 1997: 36), and developing new techniques. They are the stakeholders who force firms behave through environmental concern, so make firms act in a socially responsible way. These people are ready to sacrifice, reflecting their sensitivity.

The environmental issue can be analyzed through stakeholder theory. Stakeholder theory states that as stakeholders are legitimate partners of a firm (Westley \& Vredenburg, 1991). This theory includes three dimensions (Stead \& Stead, 2000) descriptive, instrumental, and normative. It is descriptive for its help to explain specific characteristics and behaviors. It is instrumental, because of its value to accomplish organizational goals. Finally, it is normative because, it provides a base to 'moral and philosophical foundations of an organization'. Accordingly, environmental concern should be evaluated through these points, to be a part of stakeholder view.

Henriques and Sadorsky (1999) identified four critical stakeholder groups: The first group includes regulatory stakeholders as government, trade associations, informal networks, and competitors. These elements can convince governments to intervene for natural balance. The second group consists of organizational stakeholders as customers, suppliers, employees, and shareholders who are a part of organization and a direct impact on its profitability. The third group include is called as community stakeholders and include community groups and environmental organizations that affect and establish public view. The last group is media which can have an impact on society's perception of an organization. In the frame of this research, students can be seen as a part of community groups. Also, students come from different parts of society, and reflect diversified views on any 
subject.

There is another approach from Fineman and Clarke (1996) about the classification of 'green stakeholders'. Accordingly, there are four pressure groups that concern for environmental protection. The first group has a basic mission of environmental action. The examples for them are 'Friends of the Earth', 'Greenpeace', or 'Earth First'. These are well known groups all over the world. They can use techniques like persuasion, encouragement, or confrontation. The regulatory organizations are the second group, who basically use law to protect environment. The third group consists of stakeholders who have interests from environmental based policies and practices, like consumers, suppliers, or newspapers. Finally, internal stakeholders like managers, employees or shareholders can be effective in the design and implication of environmental strategies.

Firms can act in two ways to be environmentally friendly: pro-active and re-active (Bianchi \& Noci, 1998). Pro-active behavior includes a strategic approach and action to environmental issues, while re-active attitude includes just the response to the expectations of stakeholders.

Firms should 'closely listen to the customer' and they should never forget that the company is a part of community (Taylor, 1992). As Davis (1991) stressed 'the well being of other stakeholders is as important as that of equity of shareholders. Modern, environmentally conscious consumer or 'green pressure' has many expectations that should be responded by companies (Rojsek, 2001). They should demand more to make business organizations behave through the balance of nature and human. In the frame of this aspect, firms can satisfy their stakeholders with innovation. Thus, the innovative products can respond the environmental awareness of society, while providing opportunity of high revenue for firms with their high prices.

Another important concept related with this subtopic is 'the sustainable society' which was proposed by the World Council of Churches, in 1974, emphasizing the role of democratic participation, and equitable distribution to achieve a sustainable economy. Accordingly, it shows the need of social dimension to bring a balanced earth to next generations (Dresner, 2002). In a society, which depends on democratic participation, organizations should consider the demands of people. Also, cautions that come from society can shape the operations of companies through an environmentally friendly mission and vision.

The sustainability concept is also linked with the development of human (Dresner, 2002). According to the 1996 Human Development Report, human development can provide higher economic growth in subsequent decades. This developed human potential can be reflected as higher awareness or sensitivity to environmental issues that influence enterprises.

In fact, companies can deal the issue in the frame of social responsibility. Accordingly, corporate environmental responsibility should respond all the environmental issues affected by business, and it should be a part of business policy (Bianchi \& Noci, 1998; Rojsek, 2001). Through this way, it will be easier to be integrated with society, state and other stakeholders for the goal of protecting natural balance on earth.

There are views which are supporting or against the approach that companies should behave socially responsible. The traditional perspective claims that, companies should focus on making profit, and defending the interests of shareholders. The defenders of corporate social responsibility assert that profit maximization goal cannot be efficient in two situations: if there are negative externalities and, second, when sellers have much more knowledge than buyer's, about the product (Rojsek, 2001). In the situation of externalities, the negative impact of the operations of a firm will cause reaction from society. So, the sales also might be lower. By contrast, there can also be some positive externalities that provide much more revenues, depending on an increase in public image. On the other hand, the inadequate characteristics of a product would also result in as a decline in demand. In short, it can be said that, firms should behave through mutual interests. In other words, all of the impacts, or results of a policy, operation or action should be considered effectively.

It is obvious that, to present 'green' products that satisfy customers can provide new market opportunities. Equally, as environmentally friendly actions increase efficiency through reducing waste, and environmental risk, saving costs, improving relationships with regulators and using all factors rationally, the costs of production lower. Therefore, it becomes probable to sell goods and services with lower prices (Bianchi \& Noci, 1998; Porter \& Linde, 1995; Stead \& Stead, 2000; Taylor, 1992) that also can increase revenues of a firm. As a striking sentence from Walley and Whitehead (1994), 'being green is no longer a cost of doing business; it is a catalyst for constant innovation, new market opportunity, and wealth creation'.

\subsection{Hypothesis}

As the gender can influence many areas of life, in term of differentiating approaches and behaviors the environmental awareness can change due to it. Women and men can both be sensitive for environmental issues, 
or their genes might have different tendencies for being sensitive to specific issues, or not. However, it should not be forgotten that, these all are related to the individual mindsets, knowledge or experiences. In relation to this, as women are more moderate in general, their attitude to environmental issues can also more protective. Then, it can be proposed that:

$\mathrm{H}_{1}$ ) There is a statistically significant relationship between the participants' thoughts on the environmental issues and the gender.

It is obvious that, the wealthier people are more information focused that the others. So, their information on environmental issues could make them to know how critical condition the lack of earth balance is. Thus, their consciousness on related topics would make them more active against environmentally unfriendly actions. On the other hand, individuals that have higher income levels might be ready to pay more for goods or services that respond environmental concerns. These types of individuals are also ready for donation to the activities to protect environment, or natural balance. In addition, these people are efficient in their daily life in consuming goods or service that result in as a support to related process or processes. Accordingly, it can be claimed that:

$\mathrm{H}_{2}$ ) There is a statistically significant relationship between the participants' thoughts on the environmental issues and their incomes.

As cities become larger, the political, educational, cultural, industrial, social and other related activities become larger and more sophisticated. Equally, Non-Governmental Organizations (NGO), political or philosophical schools enlarge information by presenting new approaches. These make city inhabitants more knowledgeable and politicized in all these areas. Then, they react more seriously, conscious, and in sagacity. In other words, their sensitivity to environmental issues would be larger. Also, city inhabitants can more widely feel the severe results of environmental damage more, as air pollution, or any types of pollution, large volumes of waste, or environmentally sourced diseases. So, it can be asserted that:

$\mathrm{H}_{3}$ ) There is a statistically significant relationship between the participants' thoughts on the environmental issues and the population of the cities of residence before their university education.

As reaction 1 includes the question of "How do you behave when you learn that the goods that you have purchased have hazardous effects against the environment?" it reflects an expectation of consistency between mind and behavior. In general, individuals will behave through their thoughts. It is obvious that, an individual who has sensitiveness on natural environmental issues, would react against the goods or services which have hazardous effects on environment. Therefore, it can be proposed that:

$\mathrm{H}_{4 \mathrm{a}}$ ) There is a statistically significant relationship between the participants' thoughts on the environmental issues and their reaction 1 to them.

The reaction 2 consists of the question "How is your purchasing behavior affected towards a company when you learn that its activities posit serious danger to the environment?" As it was discussed above, people (or about the research, a student) who are aware of the danger on environment might behave through the interests of nature, so humanity; and react against those firms, which have hazardous effects on environment. These bad effects can directly be related with goods or services; or they all can be about negative externalities, like gases given out from chimneys, or polluted water given to streams, rivers or seas, and any type of waste that are left out. Accordingly, it can be claimed that:

$\mathrm{H}_{4 \mathrm{~b}}$ ) There is a statistically significant relationship between the participants' thoughts on the environmental issues and their reaction 2 to them.

As a psychological or scientific reality, there should be a consistency between the thoughts of an individual and her/his attitudes. This is the harmony about personality. On the other hand, some other dimensions, like personal interests, the price of goods and services, the availability, necessities might affect the coherence between thoughts and attitudes. On the whole, the students of a university would not face hardness to achieve environmentally friendly materials. But, many environmental issues are elements of our life. So, it can be asserted that:

$\mathrm{H}_{5}$ ) There is a statistically significant relationship between the participants' thoughts on the environmental issues and their attitudes to them.

Participant's experiences on the environmental issues might change according to their gender. In other words, man and women can react in different ways due to their psychology, will, genes, education level, interest areas, vision, and expectations. In general, women can act more protective than men. On the other hand, men might be more desirous in initiating new methods, or policies to protect environment. These types of attitudes might create 
special experiences for both men and women. Thus, it would be realistic to suggest that:

$\mathrm{H}_{6}$ ) There is a statistically significant relationship between the participants' experiences on the environmental issues and the gender.

It is known that, environmentally friendly goods are more expensive. This situation can be related both with the manufacturing costs of these products, and the income level of target market. Thus, these types of goods are generally bought by the people who are the members of upper income classes. It is obvious that, the people who have low income would firstly to satisfy their essential needs. As Gandhi said in 1972, these people would not interest in environmental issues as a contrast to the behaviors of high income classes. On the other hand, donations for the environmentally friendly infrastructure, policy implementations can be associated with high income individuals. Accordingly, the attitudes of students for natural environment can be associated with the income level of their families. Hence, it can be assumed that:

$\mathrm{H}_{7}$ ) There is a statistically significant relationship between the participants' experiences on the environmental issues and the income.

As the hub of culture, academia, science, and other elements of social life large cities give opportunities to their residents to live all the dimensions of life. Again, the social relations are lived in the most complicated level. Hence, the awareness of environmental issues can be seen in large cities, especially related with the activities of Non-Governmental Organizations (NGO's). Moreover, the pollution of air, water, and noise, and the volume of cumulated waste might be correlated with the size of cities. Therefore, the natural environmental issues related experiences of individuals will be more in highly populated cities. These characteristics of urban areas make residents more sensitive to environment related problems. So, it can be claimed that:

$\mathrm{H}_{8}$ ) There is a statistically significant relationship between the participants' experiences on the environmental issues and the population of the cities of residence before their university education.

Reaction 1 includes the question of "How do you behave when you learn that the goods that you have purchased have hazardous effects against the environment?" As it was discussed above, the reactions of women and men, related with environmental issues, might differentiate. So, it can be proposed that:

$\mathrm{H}_{9 \mathrm{a}}$ ) There is a statistically significant relationship between the participants' reaction 1 to the environmental issues and the gender.

The reaction 2 consists of the question "How is your purchasing behavior affected towards a company when you learn that its activities posit serious danger to the environment?" Hence, it can be asserted that:

$\mathrm{H}_{9 b}$ ) There is a statistically significant relationship between the participants' reaction 2 to the environmental issues and the gender.

Related to the explanations above, also the following hypothesis can be presented:

$\mathrm{H}_{10 \mathrm{a}}$ ) There is a statistically significant relationship between the participants' reaction 1 to the environmental issues and the income level.

$\mathrm{H}_{10 \mathrm{~b}}$ ) There is a statistically significant relationship between the participants' reaction 2 to the environmental issues and the income level.

$\mathrm{H}_{11}$ : There is a statistically significant relationship between the participants' reaction to the environmental issues and the population of the cities of residence before their university education.

$\mathrm{H}_{12}$ ) There is a statistically significant relationship between the participants' attitudes to the environmental issues and the gender.

$\mathrm{H}_{13}$ : There is a statistically significant relationship between the participants' attitudes to the environmental issues and the income levels.

$\mathrm{H}_{14}$ : There is a statistically significant relationship between the participants' attitudes to the environmental issues and the population of the cities of residence before their university education.

$\mathrm{H}_{15 \mathrm{a}}$ : There is a statistically significant relationship between the participants' experiences on the environmental issues and their reaction 1 to them.

$\mathrm{H}_{15 \mathrm{~b}}$ : There is a statistically significant relationship between the participants' experiences on the environmental issues and their reaction 2 to them.

$\mathrm{H}_{16 \mathrm{a}}$ : There is a statistically significant relationship between the participants' attitudes to the environmental issues and their reaction 1 to them. 
$\mathrm{H}_{16 \mathrm{~b}}$ : There is a statistically significant relationship between the participants' attitudes to the environmental issues and their reaction 2 to them.

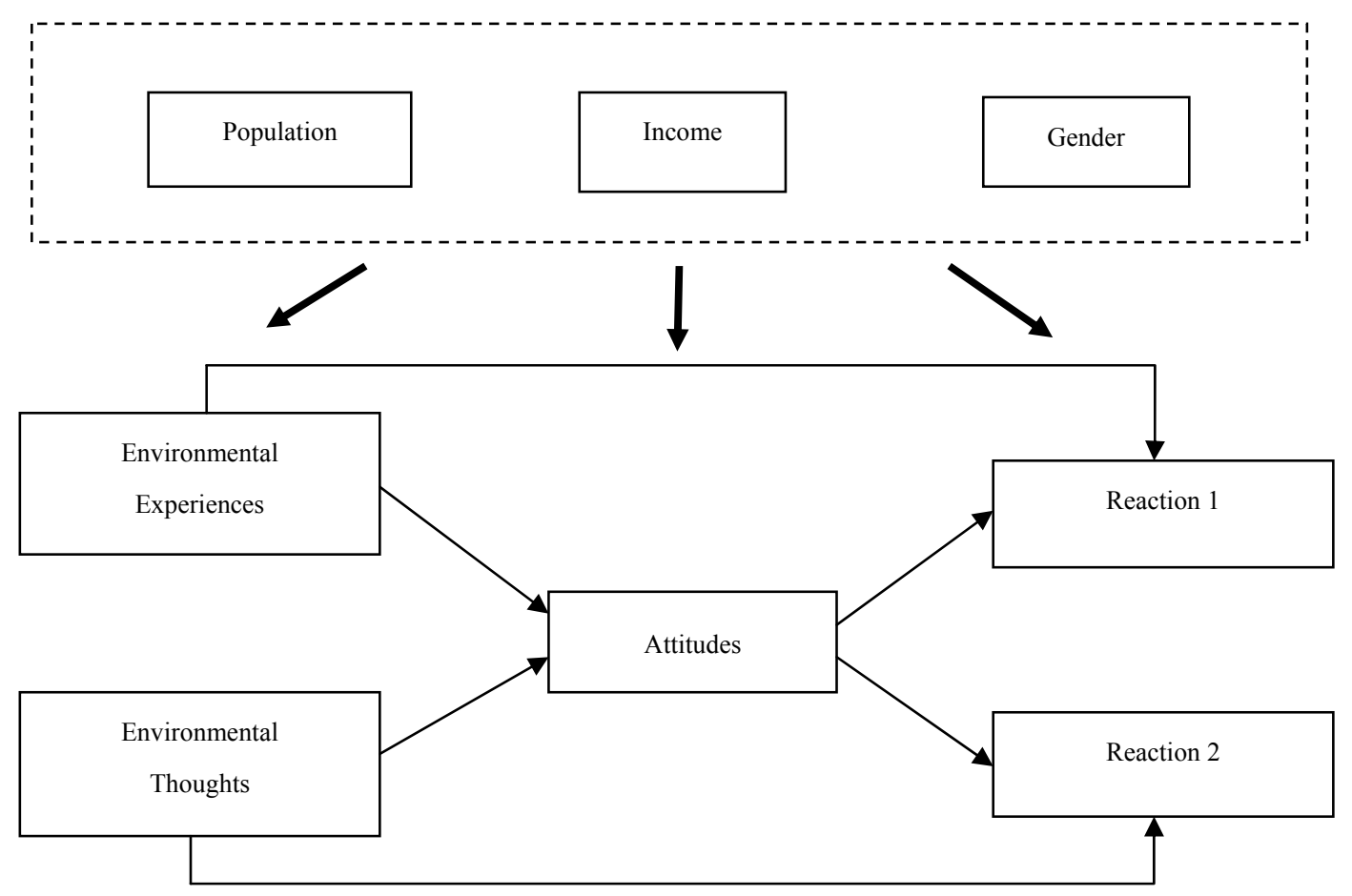

Figure 1. Research model

\section{Methodology}

\subsection{Research Goal}

In this survey we aim to identify the possible relationships among the experiences, reactions, attitudes and thoughts towards the environmental issues which have been covered under the topic of green management, and green marketing. It is also aimed to find out the effect of the demographic data pertaining to the participants on the variables discussed before. The ultimate goal put for this paper is mainly to set light on the formation of the sensitivity or responsiveness towards such issues under the hypothesis developed and to make some possible suggestions for increasing the common sense, at least throughout our sample group.

\subsection{Sample and Data Collection}

To test the hypotheses developed between the couples of variables, a questionnaire as a method of data collection was conducted on a total of 466 undergraduate students studying at the Faculty of Economics and Administrative Sciences at the Giresun University, Turkey. The questionnaire was formed with the assessment of the related literature (Demirbaş, 1999; Durali, 2002; Marangoz, 2003; Yılmaz, 2003; Ayyıldız \& Genç, 2003). Collected during February, 2014, the questionnaire included a total of 43 items using 5-point Likert's scale. In determining the sample group, the technique of convenience sampling was used due to the financial and timing limitations. After conducting a pilot test on a group of 30 students, it was decided to continue with the rest of the questionnaires on the same sample. A total of 484 participants were reached, however only 466 were found to be valid for the data analysis process. The participants were mainly the $2^{\text {nd }}$ and $4^{\text {th }}$ year-undergraduates studying at the departments of Economics, Business Management and International Relations, and took part in the questionnaire on a voluntary basis. Data obtained from those 466 questionnaires analyzed through the SPSS statistical package program, and 21 possible relations were tested. Due to the fact that the data did not show a normal distribution, which is a primary condition of using the parametric tests, non-parametric tests including Chi-Square, Mann-Whitney U and Kruskal Wallis Tests were used in testing the hypotheses.

\subsection{Analysis and Results}

A total of 43 items included in the questionnaire are grouped under 7 variables, 3 of which being the demographic ones, developed by the existing literature and personal evaluations. The variable of 'Experiences' 
is measured by 9 items, that of 'Reactions' by 2 items, that of 'Attitudes' by 9 items and that of 'Thoughts' by 19 items. According to the reliability tests conducted on these 4 variables, all the scales used are found to be reliable (Cronbach's Alpha $>0.70$ ). In order to test the content validity of the scales used, the views by 3 academics from the same university were taken, and all the scales are also found to be valid by a mean of 0,92 agreement points by these academics.

According to the descriptive statistics of the demographic questions, out of 443 valid participants, 249 (56.2\%) are females and $194(43.8 \%)$ are males.

As shown on the Table 1, out of 456 valid participants, 146 participants (32\%) have a monthly income level of 0-1000TL (app. \$400); 170 participants (37.3\%) of 1001-2000TL (\$500-1000); 91 participants (\%20) of 2001-3000TL (\$1000-1500); and 26 participants (\%5.7) of 3001-4000TL (\$1500-2000). To put it differently, 69.3 percent of the sample group live by a monthly income of 2000TL and below while only 5 percent by that of $4001 \mathrm{TL}$ and above.

Table 1. Monthly income distribution of the participants

\begin{tabular}{llllll}
\hline Monthly Income & & Frequency & Percent & Valid Percent & Cumulative Percent \\
\hline & $0-1000$ & 146 & 31.3 & 32.0 & 32.0 \\
& $1001-2000$ & 170 & 36.5 & 37.3 & 69.3 \\
\multirow{3}{*}{ Valid } & $2001-3000$ & 91 & 19.5 & 20.0 & 89.3 \\
& $3001-4000$ & 26 & 5.6 & 5.7 & 55.0 \\
& $4001-$ & 23 & 4.9 & 100.0 & 100.0 \\
\hline Missing & Total & 456 & 97.9 & & \\
\hline Total & System & 10 & 2.1 & & \\
\hline
\end{tabular}

As shown on the Table 2, out of 451 valid participants, 37 (8.2\%) lived in a residence having a population of 20.000 people and below before their university education; $42(9.3 \%)$ in that of $20.001-50.000 ; 49(10.9)$ in that of $50.001-100.000 ; 110(24.4)$ in that of $100.001-200.000 ; 48(10.6 \%)$ in that of $200.001-500.000 ; 48(10.6)$ in that of 500.001-1.000.000; $69(15.3 \%)$ in that of 1.000.001-5.000.000; and $48(10.6)$ in that of 5.000.001 and above. This also shows that $63.4 \%$ of the participants lived in the cities having a population of 500.000 people and below, which can be categorized as a 'small city' in Turkey's governmental division.

Table 2. Population of the cities of residence before the university education

\begin{tabular}{llllll}
\hline Population & & Frequency & Percent & Valid Percent & Cumulative Percent \\
\hline & $0-20.000$ & 37 & 7.9 & 8.2 & 8.2 \\
& $20.000-50.000$ & 42 & 9.0 & 9.3 & 17.5 \\
& $50.001-100.000$ & 49 & 10.5 & 10.9 & 28.4 \\
& $100.001-200.000$ & 110 & 23.6 & 24.4 & 52.8 \\
& $200.001-500.000$ & 48 & 10.3 & 10.6 & 63.4 \\
& $500.001-1.000 .000$ & 48 & 10.3 & 10.6 & 74.1 \\
& $1.000 .001-5.000 .000$ & 69 & 14.8 & 15.3 & 89.4 \\
& $5.000 .001-$ & 48 & 10.3 & 10.6 & 100.0 \\
& Total & 451 & 96.8 & 100.0 & \\
\hline Missing & System & 15 & 3.2 & & \\
\hline Total & & 466 & 100.0 & & \\
\hline
\end{tabular}

Out of 466 valid participants, $283(60.7 \%)$ are in their second year while $183(39.3 \%)$ are in their fourth year at the undergraduate degree.

The departmental divisions of the participants include 294 (63.1\% and the largest) at the department of Economics; 109 (23.4\%) at that of Management; and 63 (13.5\%) at that of International Relations as can be seen on the Table 3 below; 
Table 3. Departmental divisions of the participants

\begin{tabular}{llllll}
\hline \multicolumn{2}{l}{ Departments } & Frequency & Percent & Valid Percent & Cumulative Percent \\
\hline \multirow{4}{*}{ Valid } & Economics & 294 & 63.1 & 63.1 & 63.1 \\
\cline { 2 - 4 } & International Business & 63 & 13.5 & 13.5 & 76.6 \\
\cline { 2 - 4 } & Business Management & 109 & 23.4 & 23.4 & 100.0 \\
& Total & 466 & 100.0 & 100.0 & \\
\hline
\end{tabular}

Table 4 shows the Mann-Whitney U Test results pertaining to the relationship between the participants' thoughts on the environment and the gender. According to these results, there is not a statistically significant relationship showing the thoughts on the environment change according to the gender within our sample group ( $U=21477,5$ and sig. $>0.05$ ).

$\mathrm{H}_{1}$ is not supported.

Table 4. U-Test results between the thoughts about the environment and the gender

\begin{tabular}{lccccc}
\hline Gender & $\mathrm{N}$ & Mean Rank & Sum of Ranks & Mann Whitney U & Sig. \\
\hline Female & 248 & 228.90 & 56766.50 & 21477.500 & .094 \\
Male & 191 & 208.45 & 39813.50 & & \\
\hline
\end{tabular}

According to the Table 5, there is not a statistically significant relationship between the participants' thoughts on the environment and their income levels $\left(\mathrm{x}^{2}[\mathrm{df}=4, \mathrm{n}=452]=2,02\right.$ and sig. $\left.>0,05\right)$.

$\mathrm{H}_{2}$ is not supported.

Table 5. Kruskal wallis test result between the thoughts about the environment and the income

\begin{tabular}{|c|c|c|c|c|c|}
\hline Income & $\mathrm{N}$ & Mean Rank & $\mathrm{DF}$ & $X^{2}$ & Sig. \\
\hline $0-1000 \mathrm{TL}$ & 145 & 220.56 & & & \\
\hline $1001-2000 \mathrm{TL}$ & 169 & 229.13 & & & \\
\hline 2001-3000TL & 90 & 236.76 & 4 & 2.02 & 0.73 \\
\hline $3001-4000 \mathrm{TL}$ & 26 & 231.33 & & & \\
\hline 4001TL-above & 22 & 197.75 & & & \\
\hline
\end{tabular}

According to the Table 6 , there is a statistically significant relationship between the thoughts on the environment and the population of the cities of residence where the sample was living before their university education $\left(\mathrm{x}^{2}\right.$ $[\mathrm{df}=7, \mathrm{n}=447]=16$ and sig. $<0.05$ ). When the mean ranks are considered, the highest rank (259) belongs to the cities having the population between 500.001 and 1.000 .000 people while the lowest rank (190) belongs to the cities with a population between 50.001 and 100.000 people. These results clearly signal the fact that the population of the cities of residence that the participants were living before their university education has a determining effect on their views and thoughts about the environment. Those participants who are more attached to the environmental concerns seem to be coming from the cities having more than 500.000 population, which can be called 'a big city' in Turkey's governmental division, thus mostly being accompanied with relatively better living standards, and wider perspectives on such matters on the residents' side. On the other hand, the participants seem to be least concerned with the environmental issues come from relatively smaller cities, which could be asserted to have more 'conservative' perspectives on such issues together with the less favorable living conditions.

$\mathrm{H}_{3}$ is supported. 
Table 6. Kruskal Wallis test result between the thoughts about the environment and the population of cities of residence before the university education

\begin{tabular}{lccccc}
\hline Population & N & Mean Rank & DF & $X^{2}$ & Sig. \\
\hline $0-20.000$ & 37 & 200.41 & & & \\
$20.001-50.000$ & 42 & 214.54 & & & \\
$50.001-100.000$ & 48 & 190.97 & & & \\
$100.001-200.000$ & 110 & 251.03 & & & \\
$200.001-500.000$ & 48 & 229.60 & 7 & 16 & 0.02 \\
$500.001-1.000 .000$ & 46 & 259.54 & & & \\
$1.000 .001-5.000 .000$ & 68 & 197.02 & & & \\
$5.000 .001-$ above & 48 & 220.11 & & & \\
\hline
\end{tabular}

Kruskall Wallis Test results on the Table 7 show that there is a statistically significant difference between the participants' thoughts on the environmental issues and their reaction 1 to them $\left(\mathrm{x}^{2}[\mathrm{df}=2, \mathrm{n}=458]=14,78\right.$ and sig. $<0,05)$. Their Reaction 1 is tested with the following question;

"How do you behave when you learn that the goods that you have purchased have hazardous effects against the environment?"

Accordingly, those participants who are more engaged in the environmental issues react more harshly (I stop purchasing), with the highest mean rank of 238, than the other two groups to environmental hazards. Those who seem to be least attached to the environmental issues mostly answered that they do not change their purchasing behavior, signaled with the lowest mean rank of 129.

$\mathrm{H}_{4 \mathrm{a}}$ is supported.

Table 7. Kruskal Wallis test results between the thoughts on environment and reaction 1

\begin{tabular}{lccccc}
\hline Reactions & $\mathrm{N}$ & Mean Rank & DF & $\mathrm{X}^{2}$ & Sig. \\
\hline No change & 24 & 129,63 & & & \\
Less purchase & 226 & 231,39 & 2 & 14,78 & 0,001 \\
Stop purchasing & 208 & 238,97 & & & \\
\hline
\end{tabular}

Table 8 below shows the Kruskal Wallis Test results between the thoughts of the participant on the environment and their reaction 2 . The results signal a statistically significant difference between the participants' thoughts on the environmental issues and their reaction 2 to them $\left(\mathrm{x}^{2}[\mathrm{df}=2, \mathrm{n}=457]=6.18\right.$ and sig. $\left.<0.05\right)$. Their Reaction 2 is tested with the following question;

"How is your purchasing behavior affected towards a company when you learn that its activities posit serious danger to the environment?"

Similar to the results of the Reaction 1, those who are more engaged in the environmental issues opt for "stopping their purchasing behavior" from this company (mean rank of 234) while the levels of reactions decrease parallel with the decrease in the levels of engagement on the environmental issues. While those who are less engaged in the environmental issues than the group above opt for "purchasing less" from such a company (mean rank of 226), those with the least engagement levels opt for "not changing" their purchasing behavior (mean rank of 155).

$\mathrm{H}_{4 \mathrm{~b}}$ is supported. 
Table 8. Kruskal Wallis test results between the thoughts on environment and reaction 2

\begin{tabular}{lccccc}
\hline Reactions & $\mathrm{N}$ & Mean Rank & DF & $\mathrm{X}^{2}$ & Sig. \\
\hline No change & 18 & 155.31 & & & \\
Less purchasing & 134 & 226.40 & 2 & 6.18 & 0.045 \\
Stop purchasing & 305 & 234.49 & & & \\
\hline
\end{tabular}

Table 9 indicates the statistically meaningful relationship between the participants' thoughts on the environmental issues and their attitudes to them $\left(\mathrm{x}^{2}[\mathrm{df}=2, \mathrm{n}=462]=13,38\right.$ and sig. $\left.<0,05\right)$. Accordingly, the attitudes, or rather sensitivity about using environment-friendly products or avoiding hazardous behaviors against the environment ('always' having the highest mean rank of 252) increases as parallel to the increase in the thoughts, or concerns about the environmental issues.

$\mathrm{H}_{5}$ is supported.

Table 9. Kruskal Wallis test results between the thoughts on environment and attitudes

\begin{tabular}{llllll}
\hline Attitudes & $\mathrm{N}$ & Mean Rank & DF & $\mathrm{X}^{2}$ & Sig. \\
\hline Never & 116 & 192.34 & & & \\
From time to time & 333 & 244.31 & 2 & 13.38 & 0.001 \\
Always & 13 & 252.73 & & & \\
\hline
\end{tabular}

Table 10 below indicates that the gender is an statistically important factor in determining such experiences on the environmental issues as any membership to a NGO working on the environment, taking a course on the environment during the university education, purchasing environmental friendly products and having concerns on the green marketing $(\mathrm{U}=21330$ and sig. $<0,05)$. It is obvious that this difference basically derives from the male participants (mean rank of 235), who seem to be more experienced about such issues than the females (mean rank of 210).

$\mathrm{H}_{6}$ is supported.

Table 10. U-Test results between the experiences on environment and the gender

\begin{tabular}{lccccc}
\hline Gender & $\mathrm{N}$ & Mean Rank & Sum of Ranks & Mann Whitney U & Sig. \\
\hline Female & 248 & 210.51 & 52206 & 21330 & .040 \\
Male & 194 & 235.55 & 45697 & & \\
\hline
\end{tabular}

According to the Kruskal Wallis Test results shown on Table 11, there is not a statistically meaningful relationship between the experiences on the environmental issues and the income level of the participants $\left(\mathrm{x}^{2}\right.$ $[\mathrm{df}=4, \mathrm{n}=456]=2,62$ and sig. $>0,05)$. Thus, income level is not a determining factor in either increasing or decreasing participants' experiences mean on the environmental issues.

$\mathrm{H}_{7}$ is not supported.

Table 11. Kruskal Wallis test result between the experiences and the income

\begin{tabular}{|c|c|c|c|c|c|}
\hline Income & $\mathrm{N}$ & Mean Rank & $\mathrm{DF}$ & $\mathrm{X}^{2}$ & Sig. \\
\hline $0-1000 \mathrm{TL}$ & 146 & 218.14 & & & \\
\hline $1001-2000 \mathrm{TL}$ & 170 & 225.84 & & & \\
\hline 2001-3000TL & 91 & 242.49 & 4 & 2,62 & 0,62 \\
\hline $3001-4000 \mathrm{TL}$ & 26 & 245.81 & & & \\
\hline 4001TL-above & 23 & 239.00 & & & \\
\hline
\end{tabular}

Table 12 below shows the Kruskal Wallis Test results on the relationship between the participants' experiences on the environmental issues and their income levels. Accordingly, there is not a statistically important relationship between these two variables $\left(\mathrm{x}^{2}[\mathrm{df}=7, \mathrm{n}=450]=10.06\right.$ and sig. $\left.>0.05\right)$.

$\mathrm{H}_{8}$ is not supported. 
Table 12. Kruskal Wallis test result between the experiences on the environment and the population of cities of residence before the university education

\begin{tabular}{llllll}
\hline Population & N & Mean Rank & DF & $X^{2}$ & Sig. \\
\hline $0-20.000$ & 37 & 199.50 & & & \\
$20.001-50.000$ & 41 & 259.95 & & & \\
$50.001-100.000$ & 49 & 248.32 & & & \\
$100.001-200.000$ & 110 & 211.97 & & & \\
$200.001-500.000$ & 48 & 237.95 & 7 & 10.06 & 0.18 \\
$500.001-1.000 .000$ & 48 & 197.70 & & & \\
$1.000 .001-5.000 .000$ & 69 & 232.96 & & & \\
$5.000 .001-$ above & 48 & 228.46 & & & \\
\hline
\end{tabular}

In order to determine the relationship between the Reaction 1 and the gender, Chi-Square Test was conducted among the categories of the variables, and the results are shown on Table 13 below. Accordingly, a statistically meaningful relationship has been found $\left(\mathrm{x}^{2}[\mathrm{df}=2, \mathrm{n}=438]=6.27\right.$ and sig. $\left.<0.05\right)$. This difference mainly results from the two options of 'less purchasing' and 'stop purchasing' between the female participants and the male participants. When asked the question of "How do you behave when you learn that the goods that you have purchased have hazardous effects against the environment?", $45 \%$ percent of the females choose to purchase these goods less, $56 \%$ of males purchase the same products less. However, in terms of stopping purchasing, females $(50 \%)$ seem to be able abandon their behavior more easily than the males $(38 \%)$. It can also be inferred from the test results that almost $95 \%$ of the participants in general either purchase less or stop purchasing the products being hazardous to the environment.

$\mathrm{H}_{9 \mathrm{a}}$ is supported.

Table 13. Chi-Square test results between the reaction 1 on environment and the gender

\begin{tabular}{lcccc}
\hline & & Female & Male & Total \\
\hline No change & $\mathrm{N}$ & 12 & 11 & 23 \\
& $\%$ & 4.9 & 5.7 & 5.3 \\
Less purchasing & $\mathrm{N}$ & 111 & 108 & 219 \\
& $\%$ & 45.1 & 56.2 & 50 \\
Stop purchasing & $\mathrm{N}$ & 123 & 73 & 196 \\
& $\%$ & 50 & 38 & 44.7 \\
\hline Total & & 246 & 192 & 438 \\
& & 100 & 100 & 100 \\
\hline
\end{tabular}

According to the Table 14, which shows the Chi-Square Test results between the participants' reaction 2 and the gender, there has not been found any statistically significant relationship $\left(\mathrm{x}^{2}[\mathrm{df}=2, \mathrm{n}=437]=4,82\right.$ and sig. $\left.>0,05\right)$. To put it differently, the participants' reaction to a company when they learn that its activities posit serious danger to the environment does not change according to the gender.

$\mathrm{H}_{9 \mathrm{~b}}$ is not supported.

Table 14. Chi-Square test results between the reaction 2 on environment and the gender

\begin{tabular}{lcccc}
\hline & & Female & Male & Total \\
\hline No change & $\mathrm{N}$ & 10 & 7 & 17 \\
\multirow{3}{*}{ Less purchasing } & $\%$ & 4 & 3.7 & 3.9 \\
& $\mathrm{~N}$ & 62 & 66 & 128 \\
Stop purchasing & $\%$ & 25.1 & 34.7 & 29.3 \\
& $\mathrm{~N}$ & 175 & 117 & 292 \\
& $\%$ & 70.9 & 61.6 & 66.8 \\
\hline Total & & 247 & 190 & 437 \\
& & 100 & 100 & 100 \\
\hline
\end{tabular}


Chi-Square Test results on Table 15 indicates that there is not a statistically significant relation between the participants' reaction 1 to the environmental issues and their income levels $\left(\mathrm{x}^{2}[\mathrm{df}=8, \mathrm{n}=451]=5.12\right.$ and sig. $>0.05$ ). The income levels of the participants are not a determining factor in their reaction 1 .

$\mathrm{H}_{10 \mathrm{a}}$ is not supported.

Table 15. Chi-Square test results between the reaction 1 on environment and the income

\begin{tabular}{lccccccc}
\hline \multirow{2}{*}{ No change } & & $0-1000 \mathrm{TL}$ & $1001-2000$ & $2001-3000$ & $3001-4000$ & 4001 -above & Total \\
\hline \multirow{4}{*}{ Less purchasing } & $\mathrm{N}$ & 9 & 7 & 4 & 1 & 2 & 23 \\
& $\%$ & 6.3 & 4.1 & 4.4 & 3.8 & 8.7 & 5.1 \\
& $\mathrm{~N}$ & 63 & 87 & 47 & 14 & 14 & 225 \\
& $\%$ & 44.1 & 51.5 & 52.2 & 53.8 & 60.9 & 49.9 \\
Stop purchasing & $\mathrm{N}$ & 71 & 75 & 39 & 11 & 7 & 203 \\
& $\%$ & 49.7 & 44.4 & 43.3 & 42.3 & 30.4 & 45 \\
\hline \multirow{2}{*}{ Total } & & 143 & 169 & 90 & 26 & 23 & 451 \\
& & 100 & 100 & 100 & 100 & 100 & 100 \\
\hline
\end{tabular}

According to the Chi-Square Test results on the variables of participants' reaction 2 and their income levels, there is a statistically important relationship between them $\left(\mathrm{x}^{2}[\mathrm{df}=8, \mathrm{n}=451]=0,00\right.$ and sig. $\left.<0,05\right)$. In the category of 'no change in behavior' (18 people in total), those with a family income of 4001TL and above (app. $\$ 1700$ ) said they would keep buying the goods even if they learnt that the company's activities were hazardous to the environment, with the highest percentage. In the category of 'less purchasing' (131 in total), those with a family income of $4001 \mathrm{TL}$ and above (38\%) said they would purchase less from the company. In the category of 'stop purchasing' (302 in total), those with a family income of 2001-3000TL (app. \$800-1200) said they would stop purchasing the goods of this company. When the total figures are considered, $67 \%$ of the participants can be said to reach severely to such a condition, while $29 \%$ react less severely. These two groups comprise the $96 \%$ of the participants who said they would change their behavior in either way, which is satisfactory in terms of reflecting the environmental sensitivity among the sample group.

$\mathrm{H}_{10 \mathrm{~b}}$ is supported.

Table 16. Chi-Square test results between the reaction 2 on environment and the income

\begin{tabular}{lccccccc}
\hline & & $0-1000 \mathrm{TL}$ & $1001-2000$ & $2001-3000$ & $3001-4000$ & 4001 -above & Total \\
\hline \multirow{2}{*}{ No change } & $\mathrm{N}$ & 6 & 5 & 2 & 0 & 5 & 18 \\
& $\%$ & 4.2 & 3 & 2.2 & 0 & 21.7 & 4 \\
Less purchasing & $\mathrm{N}$ & 42 & 45 & 27 & 10 & 7 & 131 \\
& $\%$ & 29.2 & 26.8 & 30 & 38.5 & 30.4 & 29 \\
\multirow{5}{*}{ Stop purchasing } & $\mathrm{N}$ & 96 & 118 & 61 & 16 & 11 & 302 \\
& $\%$ & 66.7 & 70.2 & 67.8 & 61.5 & 47.8 & 67 \\
\hline \multirow{2}{*}{ Total } & & 144 & 168 & 90 & 26 & 23 & 451 \\
& 100 & 100 & 100 & 100 & 100 & 100 \\
\hline
\end{tabular}

In order to test any relationship between the mean ranks of the participants' reaction to the environmental issues stated on the questionnaire and the population of their cities of residence before their university education, i.e. their hometowns, Chi-Square Test was conducted. According to the results, there has not been found any related relationship between the variables $\left(\mathrm{x}^{2}[\mathrm{df}=7, \mathrm{n}=448]=7.95\right.$ and sig. $=0.33$, sig. $\left.>0.05\right)$.

$\mathrm{H}_{11}$ is not supported.

Table 17 below indicates the Mann-Whitney U Test results on the variables of attitudes to the environmental issues and the gender. According to the results, there is a statistically significant relationship between the variables $(\mathrm{U}=20987$ and sig. $<0.05)$. The meaningful difference stems from the female participants with a mean rank of 234 as opposed the male ones with that of 205 . The results also show that the female participants are more sensitive about changing their attitudes when faced with any danger against the environment.

$\mathrm{H}_{12}$ is supported. 
Table 17. U-Test results between the attitudes to environment and the gender

\begin{tabular}{lccccc}
\hline Gender & N & Mean Rank & Sum of Ranks & Mann Whitney U & Sig. \\
\hline Female & 249 & 234.71 & 58444 & 20987 & .01 \\
Male & 194 & 205.68 & 39902 & & \\
\hline
\end{tabular}

According to the Kruskal Wallis Test results on the variables of the participants' attitudes to the environmental issues and their income levels, there is no statistically meaningful relationship between the variables $\left(\mathrm{x}^{2}[\mathrm{df}=4\right.$, $\mathrm{n}=466]=7.25$ and sig. $>0.05$ ). Thus, the participants' sensitivity about changing their attitudes in the case of any hazardous activity to the environment on any company side does not differ according to their income levels.

$\mathrm{H}_{13}$ is not supported.

Table 18. Kruskal Wallis test results between the attitudes on environment and the income

\begin{tabular}{|c|c|c|c|c|c|}
\hline Income & $\mathrm{N}$ & Mean Rank & $\mathrm{DF}$ & $\mathrm{X}^{2}$ & Sig. \\
\hline $0-1000 \mathrm{TL}$ & 146 & 236.09 & & & \\
\hline $1001-2000 \mathrm{TL}$ & 170 & 240.25 & & & \\
\hline 2001-3000TL & 91 & 213.90 & 4 & 7.25 & 0.12 \\
\hline $3001-4000 \mathrm{TL}$ & 26 & 205.40 & & & \\
\hline 4001TL-above & 23 & 177.37 & & & \\
\hline
\end{tabular}

The Kruskal Wallis Test results on the Table 19 show that there is not a statistically meaningful relationship between the participants' attitudes to the environmental issues and the population of their hometowns, or of the cities where they were living before their university education $\left(\mathrm{x}^{2}[\mathrm{df}=7, \mathrm{n}=453]=3.12\right.$ and sig. $\left.>0.05\right)$.

$\mathrm{H}_{14}$ is not supported.

Table 19. Kruskal Wallis test results between the attitudes on environment and the income

\begin{tabular}{lccccc}
\hline Population & N & Mean Rank & DF & $X^{2}$ & Sig. \\
\hline $0-20.000$ & 37 & 199.12 & & & \\
$20.001-50.000$ & 42 & 239.64 & & & \\
$50.001-100.000$ & 49 & 222.78 & & & \\
$100.001-200.000$ & 110 & 223.00 & & & \\
$200.001-500.000$ & 48 & 244.40 & 7 & 3.12 & 0.87 \\
$500.001-1.000 .000$ & 48 & 226.97 & & & \\
$1.000 .001-5.000 .000$ & 69 & 227.44 & & & \\
$5.000 .001-$ above & 48 & 223.51 & & & \\
\hline
\end{tabular}

In order to find out any possible relationship between the participants' experiences on the environmental issues and their reaction 1 to them, Krusal Wallis Test was applied on the variables. According to the results found, there is no statistically significant relationship between the variables $\left(\mathrm{x}^{2}[\mathrm{df}=2, \mathrm{n}=460]=0.79\right.$ and sig. $\left.>0.05\right)$. It is also shown that any increase in the experience mean on such issues does not lead to any statistically meaningful change in the reaction 1 level in our sample group. It can be inferred that our sample is not so responsive about changing their attitudes when learning that the goods purchased by them have dangerous effects to the environment, regardless of their experience level, in statistical terms.

$\mathrm{H}_{15 \mathrm{a}}$ is not supported.

Although no relationship has been found between the participants' experience mean and their reaction 1, the test results on the Table 20 indicate that there is a statistically meaningful relationship between their experience level and their reaction $2\left(\mathrm{x}^{2}[\mathrm{df}=2, \mathrm{n}=460]=12.07\right.$ and sig. $\left.<0.05\right)$. When it comes to learning that the company is in dangerous activities to the environment, an important portion of the participants (442 out of 460) either purchase less (134) or stop purchasing (308) from this particular company. The difference between these two groups is also striking in statistical terms. Thus, it can be said that the responsiveness (2) to the environment increases with the increase in the experience level to such issues in our sample.

$\mathrm{H}_{15 \mathrm{~b}}$ is supported. 
Table 20. Kruskal Wallis test result between the experience on environment and reaction 2

\begin{tabular}{lccccc}
\hline Reaction & $\mathrm{N}$ & Mean Rank & $\mathrm{DF}$ & $\mathrm{X}^{2}$ & Sig. \\
\hline No change & 18 & 151.22 & & & \\
Purchase less & 134 & 211.72 & 2 & 12.07 & 0.002 \\
Stop purchasing & 308 & 243.31 & & & \\
\hline
\end{tabular}

Table 21 indicates the Kruskal Wallis Test results applied on the variables of the participants' attitudes mean to the environmental issues and their reaction 1 to them. Accordingly, there has been found a statistically important relationship between the variables $\left(\mathrm{x}^{2}[\mathrm{df}=2, \mathrm{n}=461]=44.41\right.$ and sig. $\left.<0.05\right)$. As the attitude mean of the participants increases, so does their reaction 1 levels. To put it differently, those participants who are the most sensitive in the environmental issues mostly opt for 'stop purchasing' with a mean rank of 247 as opposed to those having the least sensitivity about such matters, with the mean rank of 100. It is also striking that a total of 437 out of 461 participants state that they would change their attitudes in either way (purchase less or stop purchasing) when faced with any dangerous effects of the goods they have purchased.

$\mathrm{H}_{16 \mathrm{a}}$ is supported.

Table 21. Kruskal Wallis test result between the attitudes on environment and reaction 1

\begin{tabular}{lccccc}
\hline Reaction & N & Mean Rank & DF & $X^{2}$ & Sig. \\
\hline No change & 24 & 100.75 & & & \\
Purchase less & 228 & 210.89 & 2 & 44.41 & 0.00 \\
Stop purchasing & 209 & 267.89 & & & \\
\hline
\end{tabular}

As shown on the Table 22, there is a statistically significant relationship between the participants' attitudes to the environmental issues and their reaction 2 to them $\left(\mathrm{x}^{2}[\mathrm{df}=2, \mathrm{n}=460]=23.29\right.$ and sig. $\left.<0,05\right)$. Accordingly, the participants mostly (442 out of 460) opt for reacting either purchasing less or stop purchasing when faced with any dangerous situation to the environment. Those having the highest mean rank of 250 are those who said they would stop purchasing while those having the lowest mean rank of 155 are those who said they would not change their reaction even if such a situation existed.

Having parallel results with the Hypothesis $17 \mathrm{a}$, these results are satisfactory in that they signal a potential reaction to either the goods having environmental hazards or any company whose activities have been found dangerous to the environment on the participants' side.

$\mathrm{H}_{16 \mathrm{~b}}$ is supported.

Table 22. Kruskal Wallis test result between the attitudes on environment and reaction 2

\begin{tabular}{llllll}
\hline Reaction & N & Mean Rank & DF & $X^{2}$ & Sig. \\
\hline No change & 18 & 155.42 & & & \\
Purchase less & 134 & 193.81 & 2 & 23,29 & 0,00 \\
Stop purchasing & 308 & 250.85 & & & \\
\hline
\end{tabular}


Table 23. Summary of the hypotheses and test results

\begin{tabular}{lll}
\hline Hypothesis Number & Between & Result \\
\hline Hypothesis $_{1}$ & Thoughts - Gender & Not supported \\
Hypothesis $_{2}$ & Thoughts - Income & Not supported \\
Hypothesis $_{3}$ & Thoughts - Population & Supported \\
Hypothesis $_{4 \mathrm{a}}$ & Thoughts - Reaction 1 & Supported \\
Hypothesis $_{4 \mathrm{~b}}$ & Thoughts - Reaction 2 & Supported \\
Hypothesis $_{5}$ & Thoughts - Attitudes & Supported \\
Hypothesis $_{6}$ & Experience - Gender & Supported \\
Hypothesis $_{7}$ & Experience - Income & Not supported \\
Hypothesis $_{8}$ & Experience - Population & Not supported \\
Hypothesis $_{9 \mathrm{a}}$ & Reaction 1 - Gender & Supported \\
Hypothesis $_{9 \mathrm{~b}}$ & Reaction 2 - Gender & Not supported \\
Hypothesis $_{10 \mathrm{a}}$ & Reaction 1 - Income & Not supported \\
Hypothesis $_{10 \mathrm{~b}}$ & Reaction 2 - Income & Supported \\
Hypothesis $_{11}$ & Reaction - Population & Not supported \\
Hypothesis $_{12}$ & Attitudes - Gender & Supported \\
Hypothesis $_{13}$ & Attitudes - Income & Not supported \\
Hypothesis $_{14}$ & Attitudes - Population & Not supported \\
Hypothesis $_{15 \mathrm{a}}$ & Experience - Reaction 1 & Not supported \\
Hypothesis $_{15 \mathrm{~b}}$ & Experience - Reaction 2 & Supported \\
Hypothesis $_{16 \mathrm{a}}$ & Attitudes - Reaction 1 & Supported \\
Hypothesis $_{16 \mathrm{~b}}$ & Attitudes - Reaction 2 & Supported \\
\hline
\end{tabular}

\section{Conclusion}

This research has shown that, there is no statistically significant relation between the gender, income level and the thoughts of participants. Similarly, it was also revealed that, environmental experiences are not associated with the income levels or the population of city which they come from. Equally, the results of the data analysis revealed that the behavior, when it is learned 'a company posits serious danger to the environment' is not linked with gender; and when there is information that, 'purchased goods have hazardous effects against the environment' is also not linked with income levels. So, the proposal for reaction-population linkage is not supported. Besides, it was also achieved that, the attitudes of participants to environmental issues is not related with income levels or the population of the city which they lived in before. In addition, it was also seen that, the environmental experiences and reaction 1 is not associated.

The analysis of the data indicates that, the population of cities residence before their university education, their attitudes to environmental issues, and the information about purchased goods has hazardous effects against the environment, purchasing behavior to a firm which gives harm to environment, and the participants thought on environmental issues are statistically significantly associated. Moreover, the participants experiences about environmental issues and their gender is positively linked. Similarly, reactions to harmful effects on the environment, attitudes to environmental issues in general are all gender related situations. Also, customer behaviors change according to their income levels. Besides, experiences have an important role for the reactions against firms which do not act environmentally friendly. In addition, the attitudes are significantly associated with the reaction against either hazardous goods or companies.

It is clear that, as in many areas of life, women or girls have higher levels of awareness to the environmental issues. This sensitivity can be linked to their genetics. On the other hand, the largeness of city which they lived before their university education, have great impact on their attitudes, so their reaction for natural environment. Besides, it is obvious that large cities are open to any philosophy, political movement, or approach. In other words, people living in large cities are more familiar to these types of events. Thus, students coming from large cities reflect more sensitivity to environmental issues.

It also needs attention that, the participants' experiences on the environmental issues changes due to their gender. Accordingly, it can be said that, as attitudes change, so the experiences change. Thus, women have different experiences depending on their positive manner. Also, this is an indication of the position and power of women in Turkish social life.

This research also revealed that, customers' behaviors change according to their income levels. This result can be 
related and explained the general attitudes of social classes depending on income levels. Accordingly, economic conditions determine the achievability to education, markets, or any types of goods and services. So, the awareness increases with consuming all these. Also, the media and non-governmental organizations communicate information about the realities of the world. This, make people more sensitive to the current problems.

Future research should be done to clarify, whether other groups of people have similar levels and types of sensitivities or not. Therefore, new researches can be implemented among the people in non-governmental (NGO), governmental, or business organizations.

\section{Theoretical and Managerial Implications}

\subsection{Recommendations}

The researchers developed some recommendations for both researchers/theorists and management practitioners. These are:

\subsubsection{Theoretical Recommendations}

- Researchers should deeply search the questions: "How do you behave when you learn that the goods that you have purchased have hazardous effects against the environment?" Reaction 1; and, "How is your purchasing behavior affected towards a company when you learn that its activities posit serious danger to the environment?" Reaction 2, in different samples.

- The proposals of this research should be retested on other samples with related scales that allow parametric tests to be done.

- Researchers are encouraged to study further predictors of 'environmental awareness', 'environmental sensitivity', and 'environmental orientation'.

\subsubsection{Managerial Recommendations}

- Business organizations should consider the environmental awareness, or sensitivity of consumers. Accordingly, the results of this research should be utilized by firms to structure their policies on natural environmental issues. Especially, the approach of youth to these problems might be an important part of 'customer relations' or 'public relations' activities. So, the consideration of their views, can make the proposed model more beneficial.

- Firms should also establish an environmental unit to deal with these issues. This unit can both have an advisory, and policy implementation function. Hence, it can plan, coordinate, put into practice, and control related activities.

- Establishments or institutions can use the proposed model of this paper to increase the satisfaction of employees, who have environmental concerns. Therefore, their level of performances would also be higher.

\subsection{Limitations}

There were some limitations to this study. Below are some of the main ones:

- This study is limited to give only results about non-parametric tests and predictions. A non-parametric test is less sensitive than an effective parametric test, so it can be inadequate to find out the differences between groups. It will be more suitable to use parametric test on a strong data set. Non-parametric tests can be used for the data set that are nominal, ordinal, or not normally distributed.

- The data were collected through cross-sectional method and were self-reported. Thus, the potential biases can be identified.

- The results remain limited to the students of Giresun University, in Turkey. Hence, applying the result of this study in a different environment than the Giresun University, would be misleading.

\section{References}

Ayyıldız, H., \& Genç, K. Y. (2008). Çevreye duyarlı pazarlama: Üniversite öğrencilerinin çevreye duyarlı pazarlama uygulamaları ile ilgili tutum ve davranışları üzerine bir araştırma. Atatürk Üniversitesi Sosyal Bilimler Enstitüsü Dergisi, 12(2), 505-527.

Banerjee, S. B. (2001a). Managerial environmental attitudes and corporate environmentalism: A preliminary investigation. Journal of Environmental Education, 32(4), 49-50. http://dx.doi.org/10.1080/00958960109598663 
Banerjee, S. B. (2001b). Managerial perceptions of corporate environmentalism: Interpretations from industry and strategic implications for organizations. Journal of Management Studies, 38(4), 489-513. http://dx.doi.org/10.1111/1467-6486.00246

Banerjee, S. B. (2001c). Corporate environmental strategies and actions. Management Decision, 39(1), 36-44. http://dx.doi.org/10.1108/EUM0000000005405

Banerjee, S. B. (2002a). Organizational strategies for sustainable development: Developing a research agenda for the new millennium. Australian Journal of Management, 27(Special Issue), 105-117. http://dx.doi.org/10.1177/031289620202701S11

Banerjee, S. B. (2002b). Corporate environmentalism: The construct and its measurement. Journal of Business Research, 55, 177-191. http://dx.doi.org/10.1016/S0148-2963(00)00135-1

Banerjee, S. B. (2003). Who sustains whose development? Sustainable development and the reinvention of nature. Organization Studies, 24(1), 143-180. http://dx.doi.org/10.1177/0170840603024001341

Bianchi, R., \& Noci, G. (1998). Greening' SME's competitiveness. Small Business Economics 11, 269-281. http://dx.doi.org/10.1023/A:1007980420087

Clarkson, M. B. E. (1995). A stakeholder framework for analyzing and evaluating corporate social performance. Academy of Management Review, 20(1), 92-117.

Çabuk, B., \& Karacaoğlu, C. (2003). Üniversite öğrencilerinin çevre duyarlılıklarının incelenmesi. Ankara Üniversitesi Eğitim Bilimleri Fakültesi Dergisi, 36(1-2), 189-198.

Davis, J. (1991). Greening business, managing for sustainable development. Massachusetts, USA: Basic Blackwell

Decker, C. S. (2003). Corporate environmentalism and environmental statutory permitting. The Journal of Law and Economics. http://dx.doi.org/10.1086/345586

Demirbaş, M. A. (1999). Yeşil Pazarlama (Green Marketing) ve Tüketicinin Yeşil Pazarlamaya yaklaşımı (Unpublished master's thesis). Gazi University, Ankara, Turkey.

Dresner, S. (2002). The principles of sustainability. London, UK: Earthscan Publications Ltd.

Durali, H. (2002). Pazarlama-Çevre İlişkisi ve Anadolu Üniversitesi Öğrencilerinin Tüketici Olarak Çevre ile İlgili Tutum ve Davranışlarını Belirlemeye Yönelik Bir Araştırma (Unpublished master's thesis). Osmangazi University, Eskişehir, Türkey.

Egri, C. P., \& Pinfield, L. (1996). Organizations and the biosphere: Ecologies and environments. In S. R. Clegg, C. Hardy, \& W. Nord (Eds.), Handbook of organization studies. Newbury Park, CA: Sage.

Fineman, S., \& Clarke, K. (1996). Green stakeholders: Industry interpretations and response. Journal of Management Studies, 33(6), 715-730. http://dx.doi.org/10.1111/j.1467-6486.1996.tb00169.x

Fineman, S. (1997). Constructing the green manager. British Journal of Management, 8, 31-38. http://dx.doi.org/10.1111/1467-8551.00037

Gladwin, T. N., Kennelly, J. J., \& Krause, T. (1995). Shifting paradigms for sustainable development: Implications for management theory and research. Academy of Management Review, 20(4), 874-907.

Hart, S. L. (1995). A natural resource-based view of the firm. Academy of Management Review, 20(4), 986-1014.

Hart, S. L., \& Ahuja, G. (1996). Does it pay to be green? An empirical examination of the relationship between emission reduction and firm performance? Business Strategy and the Environment, 5, 30-37. http://dx.doi.org/10.1002/(SICI)1099-0836(199603)5:1<30::AID-BSE38>3.0.CO;2-Q

Heijungs, R. (2001). A theory of the environment and economic systems. Massachusetts, USA: Edward Elgar Publishing, Inc.

Henriques, I., \& Sadorsky, P. (1999). The relationship between environmental commitment and managerial perceptions of stakeholder importance. Academy of Management Journal, 42(1), 87-99. http://dx.doi.org/10.2307/256876

Hutchinson, C. (1992). Corporate strategy and the environment. Long Range Planning, 25(4), 9-21. http://dx.doi.org/10.1016/0024-6301(92)90002-J

Hutchinson, C. (1996). Integrating environment policy with business strategy. Long Range Planning, 29(1), 11-23. http://dx.doi.org/10.1016/0024-6301(95)00061-5 
Jose, P. D. (1996). Corporate strategy and the environment: A portfolio approach. Long Range Planning, 29(4), 462-472. http://dx.doi.org/10.1016/0024-6301(96)00038-6

Judge, W. Q., \& Douglas, T. J. (1998). Performance implications of incorporating natural environmental issues into the strategic planning process: An empirical assessment. Journal of Management Studies, 35(2), 241-262. http://dx.doi.org/10.1111/1467-6486.00092

Kallio, T. J., \& Nordberg, P. (2006). The evolution of organizations and natural environment discourse. Organization \& Environment, 19(4), 439-457. http://dx.doi.org/10.1177/1086026606294955

Kleiner, A. (1991). What does it to be green? Harvard Business Review, 38-47.

Lessem, R. (1991). Foreword: Greening management. In J. Davis (Ed.), Greening business: Managing for sustainable development. USA: Basic Blackwell.

MacNeill, J., Winsemius, P., \& Yakushiji, T. (1991). Beyond interdependence: The meshing of the world's economy and the earth's ecology. New York, USA: Oxford University Press.

Marangoz, M. (2003). Yeşil Pazarlama ve İşletmelerin Yeşil Pazarlama Anlayış ve Uygulamalarının Değerlendirilmesine Yönelik Bir Araştırma (Unpublished doctoral dissertation). Dokuz Eylül University, İzmir, Turkey.

Oğuz, D., Çakçı, I., \& Kavas, S. (2011). Yüksek öğretimde öğrencilerin çevre bilinci. SDÜ Orman Fakültesi Dergisi, 12, 34-39.

Perkins, R. (2007). Globalizing corporate environmentalism? Convergence and heterogeneity in Indian industry. St Comp Int Dev Springer Science and Business Media. http://dx.doi.org/10.1007/s12116-007-9007-3

Porter, M. E., \& Van der Linde, C. (1995). Green and competitive. Harvard Business Review, 120-134.

Rojsek, I. (2001). From red to green: Towards the environmental management in the country in transition. Journal of Business Ethics, 33, 37-50. http://dx.doi.org/10.1023/A:1011977116496

Rugman, A. M., \& Verbeke, A. (2000). Six cases of corporate strategic responses to environmental regulation. European Management Journal, 18(4), 377-384. http://dx.doi.org/10.1016/S0263-2373(00)00027-X

Schramm, G., \& Warford, J. J. (1989). Environmental management and economic development. Baltimore, Maryland, U.S.A.: The John Hopkins University Press. http://dx.doi.org/10.1596/0-8018-3950-5

Shrivastava, P. (1995a). Ecocentric management for a risk society. Academy of Management Review, 20(1), 118-137.

Shrivastava, P. (1995b). The role of corporations in achieving ecological sustainability. Academy of Management Review, 20(4), 936-960.

Starik, M., \& Rands, G. P. (1995). Weaving an integrated web: Multilevel and multisystem perspectives of ecologically sustainable organizations. Academy of Management Review, 20(4), 908-935.

Stead, J. G., \& Stead, E. (2000). Eco-enterprise strategy: Standing for sustainability. Journal of Business Ethics, 24, 313-329. http://dx.doi.org/10.1023/A:1006188725928

Taylor, S. R. (1992). Green management: The next competitive weapon. Futures, September, 669-680. http://dx.doi.org/10.1016/0016-3287(92)90075-Q

Taylor, G. (1993). An integrated systems approach to environmental management: A case study of IBM UK. Business Strategy and the Environment, 2(3), 1-11. http://dx.doi.org/10.1002/bse.3280020301

Walley, N., \& Whitehead, B. (1994). It is not easy being green. Harvard Business Review, 46-52.

Westley, F., \& Vredenburg, H. (1991). Strategic bridging: The collaboration between environmentalists and business in the marketing of green products. Journal of Applied Behavioural Science, 27(1), 65-90. http://dx.doi.org/10.1177/0021886391271004

Yılmaz (Öztürk), E. (2003). Sanayi İşletmeleri Açısından Çevre ve Yeşil Pazarlama (Green Marketing) (Unpublished doctoral thesis). Celal Bayar University, Manisa, Turkey.

\section{Copyrights}

Copyright for this article is retained by the author(s), with first publication rights granted to the journal.

This is an open-access article distributed under the terms and conditions of the Creative Commons Attribution license (http://creativecommons.org/licenses/by/3.0/). 